\title{
Knee osteoarthritis in obese and overweight patients: etiology and pathogenesis (literature review)
}

\author{
A.V. Sertakova, K.P. Zvereva, V.V. Zotkin, S.A. Rubashkin, D.I. Anisimov
}

Saratov State Medical University named after V.I. Razumovsky, Saratov, Russian Federation

\begin{abstract}
Introduction Based on WHO report, in 2008, the global prevalence of overweight reached over 1.4 billion people aged 20 years and over including more than 200 million men and 300 million women who suffered from obesity in 2012. More than $34 \%$ of U.S. adults are overweight, and more than $27 \%$ are obese. In European countries, the prevalence of obesity is 35-40 \% among adult population. More than 30 percent of the Russia's working population is overweight, 25 percent of whom are obese. Material and methods Search engines used included MEDLINE, the primary component of Pubmed; the Electronic Library System, products from Elsevier and Springer publishing companies; open access articles of PubMed Central; BioMed Central; Free Medical Journals and open access publications using the keywords 'knee osteoarthritis', 'etiology and pathogenesis', 'knee osteoarthritis in obesity'. Results and discussion Osteoarthritis (OA) is multifactorial in origin and closely associated with genetic predisposition, sex and age, greater body mass index (BMI) and obesity. Family history, age, gender, previous injury or abnormal mechanical loading are common risk factors of knee OA. While the above risk factors can increase the chances of developing knee OA, they are not absolute. In clinical practice, in patients with new onset of knee pain $5.1 \%$ of cases are due to previous knee injury and $24.6 \%$ related to being overweight or obese. Such metabolic factors as obesity and dyslipidemia might be involved in the pathophysiology of knee OA. Increased free radical production associated with obesity results in degradation of articular cartilage and synovial involvement. The pathogenesis of knee OA attributable to obesity is predominantly related to unfavorable mechanical environment at the joint; chronic inflammation in adipose tissue and dyslipidemia; pro-inflammatory cytokines and adipokines secreted by the adipose tissue; cytokines secreted by infrapatellar fat pad. Conclusion Inflammatory mediators of adipose origin play a major role in the initiation and perpetuation of the obesity-induced OA. There is a significant multifactorial association between OA and obesity with central roles for LDL oxyforms, HDL synthesis and excessive activation of matrix metalloproteinases, adiponectin synthesis, the release of adipokines and excessive mechanical stress.
\end{abstract}

Keywords: knee osteoarthritis, obesity, etiology, pathogenesis

\section{INTRODUCTION}

The rate of increase in the global prevalence of obesity and overweight over recent years indicates an environmental cause at the population level [1,2]. Obesity is a multifactorial condition that is caused by a combination of polygenic determinants leading to abnormal or excessive fat accumulation [1]. According to the World Health Organization (WHO), overweight is defined as a body mass index (BMI) of $\geqslant 25 \mathrm{~kg} / \mathrm{m}^{2}$ and obesity as a BMI of $\geqslant 30 \mathrm{~kg} / \mathrm{m}^{2}$. Overweight and obesity are commonly classified using body mass index (BMI). Excess body weight is an important risk factor for mortality and morbidity, increased disability and reduced life expectancy [3].

The WHO itself describes an escalating global epidemic of overweight and obesity that is taking over many parts of the world. Based on WHO report, in 2008, the global prevalence of overweight reached over 1.4 billion people aged 20 years and over including more than 200 million men and 300 million women [4]. Worldwide, the overweight and obesity population was estimated to be approximately 1.7 billion people in 2012. In 2016, 1.9 billion people worldwide were overweight [4]. More than $34 \%$ of U.S. adults are overweight, and more than $27 \%$ are obese [5]. In European countries, the prevalence of obesity is $35-40 \%$ among adult population [6]. More than 30 percent of the Russia's working population is overweight, 25 percent of whom are obese [7].

Obesity is a genuine concern for the orthopedic surgeon with the most significant impact on the musculoskeletal system and is associated with the incidence and progression of osteoarthritis (OA), knee OA, in particular.

$\mathrm{OA}$ is a heterogenic group of disorders of different etiology with similar biological, morphological and clinical manifestations and outcomes. OA is now considered a disease of the whole joint, including alterations in the articular cartilage, subchondral

Sertakova A.V., Zvereva K.P., Zotkin V.V., Rubashkin S.A., Anisimov D.I. Knee osteoarthritis in obese and overweight patients: etiology and pathogenesis (literature review). Genij Ortopedii, 2020, vol. 26, no 1, pp. 129-136. DOI 10.18019/1028-4427-202026-1-129-136 
bone, synovial membrane, ligaments, capsule and periarticular muscles [8].

The morbidity burden of OA is well documented in the WHO Global Burden of Disease Study and in multiple studies of physicians [1, 2]. Approximately 1 in 5 adults (18.2 \%) over 45 years of age in England has osteoarthritis of the knee. The prevalence ranges from around $15 \%$ to $21 \%$ across local authorities in England [9]. The estimated prevalence of knee OA is reported to be $32.3-35 \%$ in Canada and USA [10,11], $28 \%$ in Pakistan [12] and $19.3 \%$ in Iran [11]. The prevalence of knee osteoarthritis in southeast Asia with the total population of 593 million is $31-35 \%$ [13]. The burden of OA in countries with historically lower risk is expected to increase in the coming decades. The prevalence of knee OA is $21-29 \%$ in China [14]; $10.2 \%$ in India [11] and 10-16 \% in Japan [11]. The prevalence of gonarthrosis in Russia is reported in the range between 10 and $12 \%$ [15], however, a precise estimate of prevalence and incidence of the knee OA is impaired by lack of regular national surveillance systems. Worldwide estimates are that $10 \%$ of men and $18 \%$ of women have knee OA [1].

The prevalence and severity of knee OA were positively associated with obesity [16, 17]. Bessessen et al. reported that the prevalence of gonarthrosis caused by obesity was $14 \%$ among adults [18]. Lohmander et al. (22 years of observation) reported that subjects with a BMI $>30 \mathrm{~kg} / \mathrm{m}^{2}$ were 7 times more likely to develop knee OA than normal-weight controls [19]. Swedish researchers found that obese persons were 8 times more likely to develop knee
OA than normal-weight people [20]. Coggon et al. reported a 13.6 times increase in risk of gonarthrosis for a BMI of $36 \mathrm{~kg} / \mathrm{m}^{2}$ or higher for individuals aged 45 years and over [21]. The results of meta-analysis conducted by Zheng et al. [22] showed that the risk of knee OA increased by $35 \%$ with a $5 \mathrm{~kg} / \mathrm{m}^{2}$ increase in BMI. Cicuttini et al. reported a significant increase of $9-13 \%$ in risk of gonarthritis per $\mathrm{kg}$ increase in body weight [23].

The results from the Framingham Study, the Chingford Study, the Baltimore Longitudinal Study and other corroborative cross-sectional data suggested the direct correlation between obesity and progression of radiographic knee OA [2, 24, 25, 26]. Reijman et al. found that a high BMI (> $27.5 \mathrm{~kg} / \mathrm{m}^{2}$ ) in people aged $\geq 55$ years was significantly associated with progression of knee OA defined by joint space narrowing $\geq 1.5 \mathrm{~mm}$ and by an increase of minimally 1 grade in the Kellgren and Lawrence index at a 5 -year follow-up period [27]. Varus and valgus alignment at baseline was associated with a 4 -fold and 5-fold increase in risk of OA progression [28].

Therefore, many studies have been conducted to reveal the mechanisms involved in the relation between obesity and progression of knee OA. Excessive mechanical stresses on the joint are believed to play a role in aetiopathogenesis of gonarthrosis. However, this factor is only a link of a larger chain and understanding of the phenomenon is important for developing prevention strategies for disease occurence or progression.

Objective To explore aetiological and pathogenetic characteristics of knee OA in obese patients.

\section{MATERIAL AND METHODS}

Search engines used included MEDLINE, the primary component of Pubmed; the Electronic Library System, products from Elsevier and Springer publishing companies; open access articles of PubMed Central; BioMed Central; Free Medical Journals and open access publications using the keywords 'knee osteoarthritis', 'etiology and pathogenesis', 'knee osteoarthritis in obesity'. The articles discussing knee OA in individuals with normal body weight and posttraumatic obese cases were excluded from the study.

\section{RESULTS AND DISCUSSION}

Etiological risk factors, pathogenetic and anatomical characteristics for the development of knee $O A$ in obese patients

As a progressive degenerative joint disorder, knee $\mathrm{OA}$ is characterized by cartilage damage, changes in the subchondral bone, osteophyte formation and inflammation of the synovium tissue [27, 28]. OA has a multi-factorial etiology, with different sets of factors associated with its incidence including genetics, sex, age, overweight and obesity [27, 29]. Genetic traits, age, gender, preceding traumatic events or abnormal mechanical loading are common risk factors for knee OA [30, 31]. While the above risk factors can increase the chances of developing knee OA, they are not absolute. In clinical practice, in patients with new onset of knee pain $5.1 \%$ of cases are due to previous knee injury and $24.6 \%$ related to being overweight or obese [27]. Risk factors are shown in Figure 1. 


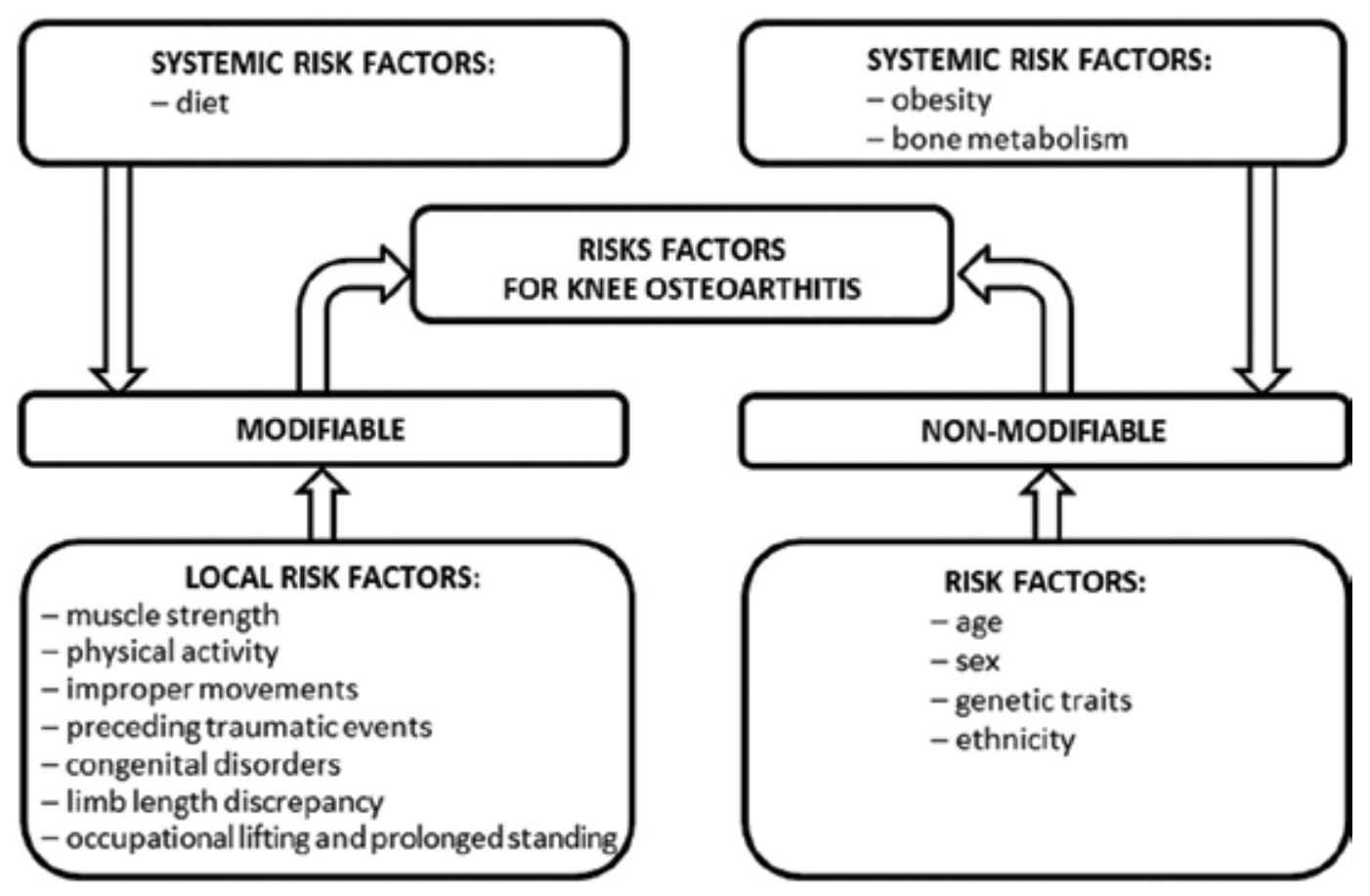

Fig. 1 Risk factors for the development of knee OA

\section{Non-modifiable risk factors for knee OA}

\section{Genetic and epigenetic risk factors}

The genetic background of knee OA likely involves about 80 genes that encode proteins with significant functions in the underlying disease process [32]. Single-nucleotide polymorphism rs143383 in the growth differentiation factor 5 (GDF5) [33] upregulating articular remodeling was reported to be associated with OA susceptibility [34]. Alterations in vitamin D receptor (VDR) and insulin-like growth factor (IGF1) regulating bone density and synovial fluid secretion [35] were shown to be involved into pathological process. Epigenetic factors were found to play a role in the development of OA .

Epigenetic factors include hereditary changes in phenotype without a change in genotype. The effects are rapidly realized and the cells use them to adapt to microenvironment contributing to progression of knee OA [36]. Major epigenetic modifications include DNA methylation, histone RNA mechanisms, MMP13 and IL- $1 \beta$ promoters that play a crutial role in the articular cartilage matrix destruction [36].

Age, cells' relationships, cell-replication program

Although older age is the greatest risk factor for $\mathrm{OA}, \mathrm{OA}$ is not an inevitable consequence of growing old [37]. Age-dependent changes involve remodeling of articular cartilage and neighboring bone, the decreased adaptive potential of the joint [37]. Age is also found to affect cell cycle control and replicative lifespan and chondrocytes can undergo a limited number of cell divisions (approximately 30-40) known as the Hayflick limit. There are also age-related changes in the structure and content of proteoglycans and proteins, increase in type II collagen cross-linking that affects cartilaginous inherent properties to reversible deformation [38]. A reduction in the number of chondrocytes is observed in normal articular cartilage during aging, increasing chondrocyte apoptosis [27, 38], decreasing lubricin (PRG-4) at the local site of the knee cavity [38]. Current researches give only partial insights into etiology and pathogesis of knee OA.

$\underline{\text { Sex }}$

Gender specific differences are observed in knee $\mathrm{OA}$. Men are reported to have a higher prevalence of OA than women before the age of 50 years, but after this age the prevalence is higher in women $[39,40]$. However, no evidence has been found with clinical trials yielding statistically significant results.

\section{Ethnicity}

The prevalence of the knee OA and patterns of joint involvement vary among different racial and ethnic groups. African women had a higher prevalence of radiographic and symptomatic knee OA [38]. We do not identify research needs and opportunities for ethnic differences in prevalence of knee osteoarthritis as essential due to universal human genetic code. 


\section{Modifiable risk factors}

Diet, overweight, obesity

Many studies suggest that the diet mainly constituted by animal fat and glucose excessive concentration and lack of nutritional factors, such as vitamins $\mathrm{C}$ and $\mathrm{D}$ may predispose to knee OA. [41, 42]. Low dietary intake of vitamins $\mathrm{E}, \mathrm{A}, \mathrm{K}$ is reported to be associated with osteophytosis and joint space narrowing in knee OA [39].

The association between obesity and knee OA suggests a more complex aetiology and pathogenesis with adipose tissue and dyslipidaemia playing a crucial role in obesity-induced OA initiation [39]. Free radicals mediate disease progression with consecutive synovial inflammation causing cartilage degradation [39].

\section{Physical activity}

Moderate physical exercise and normal mechanical stress on the joint are vital for normal metabolism in the knee joint [27]. Activities associated with repetitive movements coupled with excessive joint loading can eventually cause knee OA [43]. Participation in certain sports may be associated with gonarthrosis later in life [44].

Pathogenesis of knee $O A$ in obese patients

1. Direct effect on hyaline cartilage and chondrocytes

Cumulative joint loading (gravitational force, strain efforts) is crucial for the viability of the hyaline cartilage [45] that experiences increased strain in obesity. Overweight and obesity cause increased compression forces on the medial and lateral aspects of the knee joint [45], biomechanically pathological gait due to different reasons results in cumulative articular strain [46] creating mechanical stress to the cartilage/subchondral bone. An increased expression of metabolic enzymes MMP-1, MMP-3, MMP-9 participating in degradation of proteoglycans and cartilaginous matrix is observed in non-weight-bearing areas [47]. Excessive mechanical stress significantly inhibits DNA synthesis of articular cartilage collagens and proteoglycans, and modulates inflammatory status of chondrocytes [47]. Furthrer, chondrocytes express the cascade of pro-inflammatory cytokines IL-1ß,

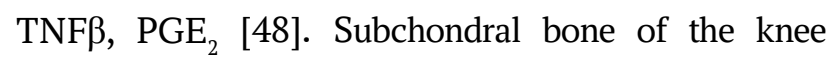
responds with identical changes in osteocytes [47].

2. Dyslipidemia

Dyslipidemia plays an important role in pathogenesis of knee OA associated with obesity.
The primary dyslipidemia related to obesity is characterized by increased triglycerides (TGs), decreased high density lipoprotein (HDL) and cholesterol levels, elevated free fatty acid (FFA) and free radical levels and abnormal low density lipoprotein (oxLDL) composition [49]. HDL functionality is reduced in obesity [50] and results in poor chylomicron production. Elevated levels of serum cholesterol and Tgs are associated with the risk of generalized OA and bone marrow failure [50]. Bone marrow failure causes chronic pain in knee OA and contributes to the hyaline cartilage loss [51, 52]. High synovial concentration of oxidized LDL activates lectin-like oxLDL receptor 1 (LOX-1) in obesity that triggers synthesis of vascular endothelial growth factor (VEGF) in chondrocytes [48]. Higher VEGF concenrations are shown to induce production of cytokines involved in cartilage degradation (MMP 1,3,13; IL-1 $\beta$, IL-6, TNF $\alpha$ ) [53].

Intra-articular macrophages are activated by elevated FFA concentrations [54] via universal cellular TOLL-receptors. They release TNF $\alpha$ and develop into M1-proinflammatory macrophages attacking infrapatellar fat pads and attracting T/B-lymphocytes, neurophils to the site of inflammation [47]. Excessive infrapatellar fat pads are found to be an additional source of degrading cytokines, adipokines and leptin in obesity [55]. Major mediators and their effects on the knee joint are presented in Table 1.

Infrapatellar fat pad (IPFP) supports high levels of cytokines, adipokines and leptins intra-articularly. Together, the factors mentioned negatively affect joint tissues, eventually resulting in OA development.

Resistin, chemerin, lipocalin-2 and visfatin are newly identified adipokines that have been implicated in OA development. Data on these adipokines and their effects on joint tissues, together with a summary of the effects of leptin and adiponectin, can be found in Table I.

The authors identified essential pathogenetic aspects of the knee OA and presented multifactorial association between obesity and knee OA in Figure 2 .

Therefore, excessive mechanical stress on the joint, chronic adipose tissue inflammation and dyslipidaemia, pro-inflammatory cytokines and adipokines secreted by adipose tissue, cytokines secreted by infrapatellar fat pad play a crucial role in pathogenesis of knee OA in obese individuals. 
Table 1

Adipokines and their effects on the knee joint in obesity

\begin{tabular}{|l|l|l|l|l|l|}
\hline Mediator & $\begin{array}{l}\text { Expression } \\
\text { in obesity }\end{array}$ & $\begin{array}{l}\text { Association with } \\
\text { knee OA severity, } \\
\text { positive/negative }\end{array}$ & $\begin{array}{c}\text { Effect on } \\
\text { subchondral bone }\end{array}$ & Effect on synovium & \multicolumn{1}{|c|}{$\begin{array}{c}\text { Effect on hyaline } \\
\text { cartilage }\end{array}$} \\
\hline Leptin & increased & positive & $\begin{array}{l}\text { Reduced } \\
\text { subchondral bone } \\
\text { thickness }\end{array}$ & $\begin{array}{l}\text { Increased expression } \\
\text { of inflammatory } \\
\text { cytokines }\end{array}$ & $\begin{array}{l}\text { proteoglycan depletion, } \\
\text { destruction of hyaline } \\
\text { cartilage }\end{array}$ \\
\hline Adiponectin & decreased & negative & $\begin{array}{l}\text { Increased } \\
\text { proteoglycan } \\
\text { production in } \\
\text { synovium }\end{array}$ & $\begin{array}{l}\text { Increased release of } \\
\text { inflammatory cytokines }\end{array}$ \\
\hline Resistin & increased & positive & $\begin{array}{l}\text { Nynovitis upon } \\
\text { resistin injection, } \\
\text { increased expression } \\
\text { of inflammatory } \\
\text { cytokines in } \\
\text { synoviocytes }\end{array}$ & $\begin{array}{l}\text { Increased expression } \\
\text { of proinflammatory } \\
\text { cytokines, chemokines, } \\
\text { decreased collagen type II } \\
\text { and aggrecan expression, } \\
\text { decreased proteoglycan } \\
\text { synthesis }\end{array}$ \\
\hline Visfatin & increased & positive & $\begin{array}{l}\text { Increased } \\
\text { subchondral } \\
\text { bone erosion } \\
\text { and increased } \\
\text { expression of } \\
\text { inflammatory } \\
\text { cytokines }\end{array}$ & $\begin{array}{l}\text { Increased synovitis, } \\
\text { upregulated } \\
\text { inflammatory } \\
\text { cytokines in } \\
\text { synoviocytes }\end{array}$ & $\begin{array}{l}\text { expression of } \\
\text { proinflammatory } \\
\text { cytokines, chemokines, } \\
\text { decreased collagen type II } \\
\text { and aggrecan expression, } \\
\text { decreased proteoglycan } \\
\text { synthesis }\end{array}$ \\
\hline Lipocalin-2 & increased & positive & No effects reported & $\begin{array}{l}\text { Inhibits } \\
\text { autodegradation in } \\
\text { synovial fibroblasts }\end{array}$ & $\begin{array}{l}\text { Increased } \\
\text { glycosaminoglycan } \\
\text { release in articular } \\
\text { chondrocytes }\end{array}$ \\
\hline increased & positive & $\begin{array}{l}\text { Attracts pro- } \\
\text { inflammatory } \\
\text { cells to cites of } \\
\text { inflammation }\end{array}$ & $\begin{array}{l}\text { Increased cytokine release } \\
\text { in articular chondrocytes }\end{array}$ \\
\hline
\end{tabular}

Note: courtesy of Thijssen et al., 2015 [44].

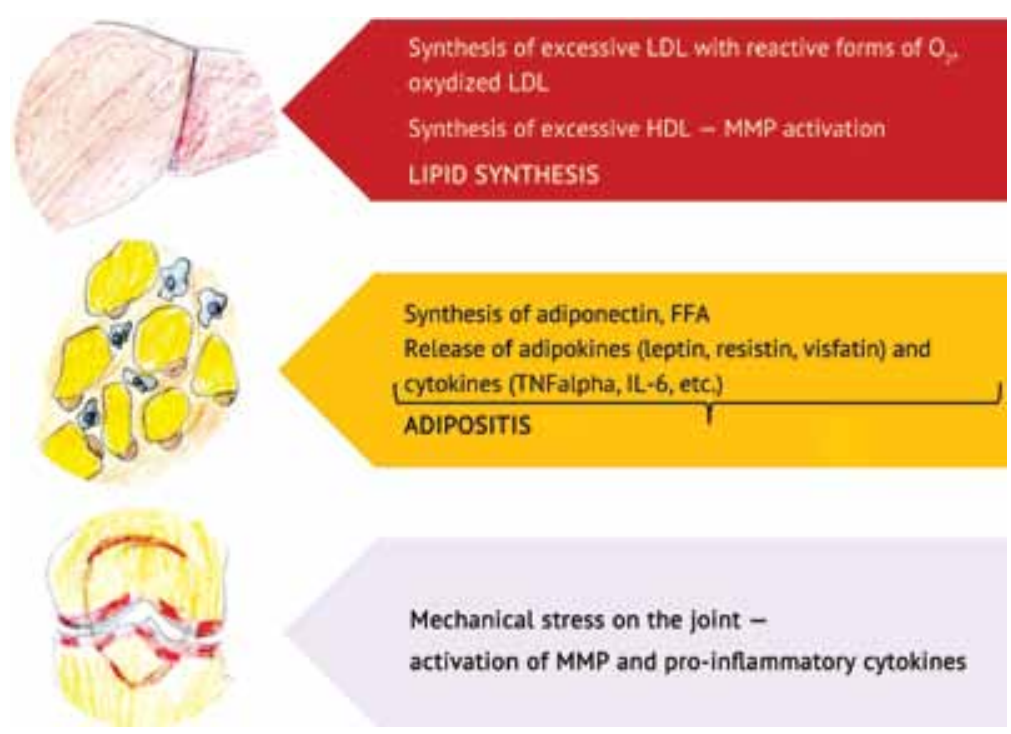

Fig. 2 Association between obesity and knee OA, where TG - triglycerides, LDL - low-density lipoprotein, HDL - highdensity lipoprotein, MMP - matrix metalloproteinase, FFA - free fatty acids

\section{Clinical presentation and diagnosis}

Persistent knee joint pain, morning stiffness lasting > 15-20 minutes, decreased range of motion, crepitus and joint deformity are highly suggestive of knee OA [56, 57]. The pain of knee OA may range from a mild ache to a severe, burning sensation which often worsens with movement and eases with rest $[56,57]$. Recurrent synovitis and knee OA can cause 
more persistent rest and night pain. The most highly reliable signs identified by physical examination of the OA knee include joint malalignment, local swelling, limited range of motion, general passive crepitus, valgus/varus of the knee [56, 57].

When evaluating patients with osteoarthritis of the knee, AP and lateral radiographs allow an adequate evaluation of the medial and lateral joint spaces. This evaluation can also be accomplished with magnetic resonance imaging (MRI) studies [58]. Radiographic findings in patients with osteoarthritis include joint space narrowing, marked osteophyte formation as well as subchondral new bone formation [58]. MRI is useful for the detection of ongoing knee instability, synovitis and evident limitation in ROM. MRI can be helpful in evaluating the integrity of the hyaline articular cartilage, subarticular bone abnormalities, subchondral cysts, meniscus changes, the cruciate ligaments and collateral ligaments, synovitis and intra-articular free bodies [59]. Commonly used laboratory tests (common blood count, biochemical screening) do not indicate to pathological changes in classical knee OA even in secondary synovitis and it serves a diagnostic criterion for differential diagnosis of the knee condition [60].

\section{CONCLUSION}

Obesity is an epidemic of the 21th century and has far-reaching effects on the musculoskeletal system and associated conditions such as knee OA osteoarthritis and other increasingly prevalent conditions. Inflammatory mediators of adipose origin play a major role in the initiation and perpetuation of the obesity-induced OA. There is a significant multifactorial association

between OA and obesity with central roles for LDL oxyforms, HDL synthesis and excessive activation of matrix metalloproteinases, adiponectin synthesis, the release of adipokines and excessive mechanical stress. Preliminary regulation of lipid homeostasis and elimination of adipose tissue using medications and non-drug therapy is essential in the case.

\section{REFERENCES}

1. Razina A.O., Achkasov E.E., Runenko S.D. Ozhirenie: sovremennyi vzgliad na problem [Obesity: A Modern look at the problem]. Ozhirenie i Metabolizm, 2016, vol. 13, no. 1, pp. 3-8. DOI: 10.14341/omet201613-8. (in Russian)

2. Strebkova E.A, Alekseeva L.I. Osteoartroz i ozhirenie [Osteoarthrosis and obesity]. Nauchno-Prakticheskaia Revmatologiia, 2015, vol. 53, no. 51, pp. 542-552. (in Russian)

3. Nasonova V.A., Mendel O.I., Denisov L.N., VertkinA.L.,Alekseeva L.I., NaumovA.V. Osteoartroz i ozhirenie: kliniko-patogeneticheskie vzaimosviazi [Osteoarthrosis and obesity: Clinical and pathogenetic relationships]. Profilakticheskaia Meditsina, 2011, vol. 14, no. 1, pp. 29-37. (in Russian)

4. Verbovoi A.F. Ozhirenie, manifestirovavshee v pubertatnyi period [Obesity manifested at the puberty]. Samara, Ofort, $2012,92 \mathrm{p}$. (in Russian)

5. Hruby A., Hu F.B. The Epidemiology of Obesity: A Big Picture. Pharmacoeconomics, 2015, vol. 33, no. 7, pp. 673-689. DOI: 10.1007/s40273-014-0243-x.

6. Stevens G.A., Singh G.M., Lu Y., Danaei G., Lin J.K., Finucane M.M., Bahalim A.N., McIntire R.K., Gutierrez H.R., Cowan M., Paciorek C.J., Farzadfar F., Riley L., Ezzati M.; Global Burden of Metabolic Risk Factors of Chronic Diseases Collaborating Group (Body Mass Index). National, regional, and global trends in adult overweight and obesity prevalences. Popul. Health Metr., 2012, vol. 10, no. 1, pp. 22. DOI: 10.1186/1478-7954-10-22.

7. Dedov I.I., Melnichenko G.A., eds. Ozhirenie: etiologiia, patogenez, klinicheskie aspekty: ruk.dlia vrachei [Obesity: etiology, pathogenesis, clinical aspects: Guide for physicians]. M., Med. Inform. Agentstvo, 2006. 452 p. (in Russian)

8. Klinicheskie rekomendatsii po diagnostike i lecheniiu osteoartroza [Clinical recommendations on diagnosis and treatment of osteoarthrosis]. Obshcheros. Obshchestvennaia Organizatsiia «Assotsiatsiia Revmatologov Rossii». 2013, 19 p. (in Russian)

9. Prevalence of osteoarthritis in England and local authorities: Birmingham First bulletin highlighting data from the new Musculoskeletal Calculator. Source: (c) Crown copyright 2014 Public Health Outcomes Framework accessed via http://www. phoutcomes.info/ 28th September 2014.

10.Gaudreault N., Durand M.J., Moffet H., Hebert L., Hagemeister N., Feldman D., Bernier M., Genest K., Laprise S., Maynard-Paquette A.-C. Literature Review of Risk Factors, Evaluation Instruments, and Care and Service Interventions for Knee Osteoarthritis. National Library and Archives of Quebec, 2015.

11.Litwic A., Edwards M.H., Dennison E.M., Cooper C. Epidemiology and Burden of Osteoarthritis. Br. Med. Bull., 2013, vol. 105, pp. 185-199. DOI: 10.1093/bmb/lds038.

12.Islam A.S., Akanda B.H., Bakhtiar, Haque M., Roy R.Ch., Arefin A., Musa A.S. Prevalence of Osteoarthritis among Ethnic Communities in Bangladesh. EC Orthopaedics, 2016, vol. 3, no. 2, pp. 284-289.

13.Nguyen T.V. Osteoarthritis in southeast Asia. Int. J. Clin. Rheumatol., 2014, vol. 9, no. 5, pp. 405-408.

14.Liu S.C., Hou Z.L., Tang Q.X., Qiao X.F., Yang J.H., Ji Q.H. Effect of knee joint function training on joint functional rehabilitation after knee replacement. Medicine, 2018, vol. 97, no. 28, pp. e11270. DOI: 10.1097/MD.0000000000011270.

15.Matveev R.P., Bragina S.V. Osteoartroz kolennogo sustava: problem i sotsialnaia znachimost [Osteorthrosis of the knee: Problems and social significance]. Ekologiia Cheloveka, 2012, no. 9, pp. 53-62. (in Russian)

16.Bessesen D., Kushner R. Evaluation \& Management of Obesity. Philadelphia, Hanley \& Belfus, 2002, 190 p. 
17.Lohmander L.S., Gerhardsson de Verdier M., Rollof J., Nilsson P.M., Engström G. Incidence of severe knee and hip osteoarthritis in relation to different measures of body mass: a population-based prospective cohort study. Ann. Rheum. Dis., 2009, vol. 68, no. 4, pp. 490-496. DOI: 10.1136/ard.2008.089748.

18.Toivanen A.T., Heliövaara M., Impivaara O., Arokoski J.P., Knekt P., Lauren H., Kröger H. Obesity, physically demanding work and traumatic knee injury are major risk factors for knee osteoarthritis - a population-based study with a follow-up of 22 years. Rheumatology (Oxford), 2010, vol. 49, no. 2, pp. 308-314. DOI: 10.1093/rheumatology/kep388.

19.D. Coggon, I. Reading, P. Croft, M. McLaren, D. Barrett, C. Cooper. Knee osteoarthritis and obesity. Int. J. Obes. Relat. Metab. Disord., 2001, vol. 25, no. 5, pp. 622-627.

20.Zheng H., Chen C. Body mass index and risk of knee osteoarthritis: systematic review and meta-analysis of prospective studies. BMJ Open, 2015, vol. 5, no. 12, pp. e007568. DOI: 10.1136/bmjopen-2014-007568.

21.Cicuttini F.M., Baker J.R., Spector T.D. The association of obesity with osteoarthritis of the hand and knee in women: a twin study. J. Rheumatol., 1996, vol. 23, no. 7, pp. 1221-1226.

22.Felson D.T., Zhang Y., Hannan M.T., Naimark A., Doyle D.V. Risk factors for incident radiographic knee osteoarthritis in the elderly: the Framingham Study. Incidence and progression of osteoarthritis in women with unilateral knee disease in the general population: the effect of obesity. Ann. Rheum. Dis., 1994, vol. 53, no. 9, pp. 565-568.

23.Spector T.D., Hart D.J., Doyle D.V. Incidence and progression of osteoarthritis in women with unilateral knee disease in the general population: the effect of obesity. Ann Rheum Dis., 1994, vol. 53, pp. 565-568.

24.Hochberg M.C., Lethbridge-Cejku M., Scott W.W. Jr., Reichle R., Plato C.C., Tobin J.D. The association of body weight, body fatness and body fat distribution with osteoarthritis of the knee: data from the Baltimore Longitudinal Study of Aging. J. Rheumatol., 1995, vol. 22, no. 3, pp. 488-493.

25.Reijman M., Pols H.A., Bergink A.P., Hazes J.M., Belo J.N., Lievense A.M., Bierma-Zeinstra S.M. Body mass index associated with onset and progression of osteoarthritis of the knee but not of the hip: The Rotterdam Study. Ann. Rheum. Dis., 2007, vol. 66, no. 2, pp. $158-162$.

26.Messier S.P., Pater M., Beavers D.P., Legault C., Loeser R.F., Hunter D.J., DeVita P. Influences of alignment and obesity on knee joint loading in osteoarthritic gait. Osteoarthritis Cartilage, 2014, vol. 22, no. 7, pp. 912-917. DOI: 10.1016/j.joca.2014.05.013.

27.Musumeci G., Aiello F.C., Szychlinska M.A., Di Rosa M., Castrogiovanni P., Mobasheri A. Osteoarthritis in the XXIst Century: Risk Factors and Behaviours that Influence Disease Onset and Progression. Int. J. Mol. Sci., 2015, vol. 16, no. 3, pp. $6093-6112$. DOI: 10.3390/ijms16036093.

28.Kavalerskii G., Smetanin S., Lychagin A., Moisov A. Faktory riska razvitiia osteoartroza kolennogo sustava [Risk factors for developing the knee osteoarthrosis]. Vrach, 2017, no. 3, pp. 22-24. (in Russian)

29.Norkin I.A., Sertakova A.V., Rubashkin S.A., Zotkin V.V., Gerasimov V.A., Timaev M.Kh., Chibrikova Iu.A., Kupina E.S. Koksartroz detskogo i podrostkovogo vozrasta: vozmozhnye puti profilaktiki [Coxarthrosis of childhood and adolescence: possible ways of prevention]. Saratovskii Nauchno-Meditsinskii Zhurnal, 2017, vol. 13, no. 3, pp. 751-755. (in Russian)

30.Ramos Y.F., Den Hollander W., Bovée J.V., Bomer N., Van der Breggen R., Lakenberg N., Keurentjes J.C., Goeman J.J., Slagboom P.E., Nelissen R.G., Bos S.D., Meulenbelt I. Genes involved in the osteoarthritis process identified through genome wide expression analysis in articular cartilage; the RAAK study. PLoS One, 2014, vol. 9, no. 7, pp. e103056. DOI: 10.1371/journal.pone.

31.Silverwood V., Blagojevic-Bucknall M., Jinks C., Jordan J.L., Protheroe J., Jordan K.P. Current evidence on risk factors for knee osteoarthritis in older adults: A systematic review and meta-analysis. Osteoarthritis Cartilage, 2015, vol. 23, no. 4, pp. 507-515. DOI: 10.1016/j.joca.2014.11.019.

32.Ryder J.J., Garrison K., Song F., Hooper L., Skinner J., Loke Y., Loughlin J., Higgins J.P., MacGregor A.J. Genetic associations in peripheral joint osteoarthritis and spinal degenerative disease: A systematic review. Ann. Rheum. Dis., 2008, vol. 67, no. 5, pp. 584-591.

33.Khan I.M., Redman S.N., Williams R., Dowthwaite G.P., Oldfield S.F., Archer C.W. The development of synovial joints. Curr. Top. Dev. Biol., 2007, vol. 79, pp. 1-36. DOI: 10.1016/S0070-2153(06)79001-9.

34.Reynard L.N., Loughlin J. Genetics and epigenetics of osteoarthritis. Maturitas, 2012, vol. 71, no. 3, pp. 200-204. DOI: 10.1016/j. maturitas.2011.12.001.

35.Felson D.T., Lawrence R.C., Dieppe P.A., Hirsch R., Helmick C.G., Jordan J.M., Kington R.S., Lane N.E., Nevitt M.C., Zhang Y., Sowers M., McAlindon T., Spector T.D., Poole A.R., Yanovski S.Z., Ateshian G., Sharma L., Buckwalter J.A., Brandt K.D., Fries J.F. Osteoarthritis: new insights. Part 1: The disease and its risk factors. Ann. Intern. Med., 2000, vol. 133, no. 8, pp. 635-646.

36.Hashimoto K., Otero M., Imagawa K., De Andrés M.C., Coico J.M., Roach H.I., Oreffo R.O., Marcu K.B., Goldring M.B. Regulated transcription of human matrix metalloproteinase 13 (MMP13) and interleukin-1 $\beta$ (IL1B) genes in chondrocytes depends on methylation of specific proximal promoter CpG Sites. J. Biol. Chem., 2013, vol. 288, no. 14, pp. 10061-10072. DOI: 10.1074/ jbc.M112.421156.

37.Mobasheri A., Matta C., Zákány R., Musumeci G. Chondrosenescence: Definition, hallmarks and potential role in the pathogenesis of osteoarthritis. Maturitas, 2015, vol. 80, no. 3, pp. 237-244. DOI: 10.1016/j.maturitas.2014.12.003.

38.Musumeci G., Trovato F.M., Loreto C., Leonardi R., Szychlinska M.A., Castorina S., Mobasheri A. Lubricin expression in human osteoarthritic knee meniscus and synovial fluid: a morphological, immunohistochemical and biochemical study. Acta Histochem., 2014, vol. 116, no. 5, pp. 965-972. DOI: 10.1016/j.acthis.2014.03.011.

39.Jiang L., Zhu X., Rong J., Xing B., Wang S., Liu A., Chu M., Huang G. Obesity, osteoarthritis and genetic risk: The rs182052 polymorphism in the ADIPOQ gene is potentially associated with risk of knee osteoarthritis. Bone Joint Res., 2018, vol. 7, no. 7, pp. 494-500. DOI: 10.1302/2046-3758.77.BJR-2017-0274.R1.

40.Thysen S., Luyten F.P., Lories R.J. Targets, models and challenges in osteoarthritis research. Dis. Model. Mech., 2015, vol. 8, no. 1, pp. 17-30. DOI: 10.1242/dmm.016881.

41.Sartori-Cintra A.R., Aikawa P., Cintra D.E. Obesity versus osteoarthritis: beyond the mechanical overload. Einstein (Sao Paulo), 2014, vol. 12, no. 3, pp. 374-379.

42.Sanghi D., Mishra A., Sharma A.C., Raj S., Mishra R., Kumari R., Natu S.M., Agarwal S., Srivastava R.N. Elucidation of dietary risk factors in osteoarthritis knee - a case-control study. J. Am. Coll. Nutr., 2015, vol. 34, no. 1, pp. 15-20. DOI: 10.1080/0731572 4.2013.875439. 
43.Di Rosa M., Szychlinska M.A., Tibullo D., Malaguarnera L., Musumeci G. Expression of CHI3L1 and CHIT1 in osteoarthritic rat cartilage model. A morphological study. Eur. J. Histochem., 2014, vol. 58, no. 3, pp. 2423. DOI: 10.4081/ejh.2014.2423.

44.Thijssen E., van Caam A., van der Kraan P.M. Obesity and osteoarthritis, more than just wear and tear: pivotal roles for inflamed adipose tissue and dyslipidaemia in obesity-induced osteoarthritis. Rheumatology, 2015, vol. 54, no. 4, pp. . 588-600. DOI: 10.1093/ rheumatology/keu464.

45.Widmyer M.R., Utturkar G.M., Leddy H.A., Coleman J.L., Spritzer C.E., Moorman C.T. 3rd, DeFrate L.E., Guilak F. High body mass index is associated with increased diurnal strains in the articular cartilage of the knee. Arthritis Rheum., 2013, vol. 65, no. 10, pp. 2615- 2622. DOI: 10.1002/art.38062.

46.Harding G.T., Hubley-Kozey C.L., Dunbar M.J., Stanish W.D., Astephen Wilson J.L. Body mass index affects knee joint mechanics during gait differently with and without moderate knee osteoarthritis. Osteoarthritis Cartilage, 2012, vol. 20, no. 11, pp. $1234-1242$. DOI: 10.1016/j.joca.2012.08.004.

47.He Y., Yao W., Zhang M., Zhang Y., Zhang D., Jiang Z., Ma T., Sun J., Shao M., Chen J. Changes in osteogenic gene expression in hypertrophic chondrocytes induced by SIN-1. Exp. Ther. Med., 2018, vol. 16, no. 2, pp. 609-618. DOI: 10.3892/etm.2018.6261.

48.Fermor B., Weinberg J.B., Pisetsky D.S., Misukonis M.A., Fink C., Guilak F. Induction of cyclooxygenase-2 by mechanical stress through a nitric oxide-regulated pathway. Osteoarthritis Cartilage, 2002, vol. 10, no. 10, pp. 792-798.

49.Klop B., Elte J.W., Cabezas M.C. Dyslipidemia in obesity: mechanisms and potential targets. Nutrients, 2013, vol. 5, no. 4, pp. 12181240. DOI: 10.3390/nu5041218.

50.Wang H., Peng D.Q. New insights into the mechanism of low high-density lipoprotein cholesterol in obesity. Lipids Health Dis., 2011, vol. 10, pp. 176. DOI: 10.1186/1476-511X-10-176.

51.Davies-Tuck M.L., Hanna F., Davis S.R., Bell R.J., Davison S.L., Wluka A.E., Adams J., Cicuttini F.M. Total cholesterol and triglycerides are associated with the development of new bone marrow lesions in asymptomatic middle-aged women - a prospective cohort study. Arthritis Res Ther., 2009, vol. 11, no. 6, pp. R181.

52.Triantaphyllidou I.E., Kalyvioti E., Karavia E., Lilis I., Kypreos K.E., Papachristou D.J. Perturbations in the HDL metabolic pathway predispose to the development of osteoarthritis in mice following long-term exposure to western-type diet. Osteoarthritis Cartilage, 2013, vol. 21, no. 2, pp. 322-330. DOI: 10.1016/j.joca.2012.11.003.

53.Akagi M., Ueda A., Teramura T., Kanata S., Sawamura T., Hamanishi C. Oxidized LDL binding to LOX-1 enhances MCP-1 expression in cultured human articular chondrocytes. Osteoarthritis Cartilage, 2009, vol. 17, no. 2, pp. 271-275. DOI: 10.1016/j.joca.2008.06.019.

54.Han J.M., Levings M.K. Immune regulation in obesity-associated adipose inflammation. J. Immunol., 2013, vol. 191, no. 2, pp. 527532. DOI: 10.4049/jimmunol.1301035.

55.Kang Y.E., Kim J.M., Joung K.H., Lee J.H., You B.R., Choi M.J., Ryu M.J., Ko Y.B., Lee M.A., Lee J., Ku B.J., Shong M., Lee K.H., Kim H.J. The Roles of Adipokines, Proinflammatory Cytokines, and Adipose Tissue Macrophages in Obesity-Associated Insulin Resistance in Modest Obesity and Early Metabolic Dysfunction. PLoS One, 2016, vol. 11, no. 4, pp. e0154003.

56.Badokin V.V. Osteoartroz kolennogo sustava: klinika, diagnostika, lechenie [Osteoarthrosis of the knee: clinical picture, diagnosis, treatment]. Sovremennaia Revmatologiia, 2013, vol. 7, no. 3, pp. 70-75. (in Russian)

57.Uriasev O.M., Zaigrova N.K. Osteoartrit: patogenez, diagnostika, lechenie [Osteoarthritis: pathogenesis, diagnosis, treatment]. Zemskii Vrach, 2016, no. 1-2, pp. 29-30. (in Russian)

58.Matveev R.P., Bragina S.V. Diagnostika osteoartroza kolennogo sustava: ucheb. posobie [Diagnosis of the knee osteoarthrosis: manual]. Arkhangelsk, Izd-vo Sever. Gos. Med. Un-ta, 2015, 64 p. (in Russian)

59.Burnett C., Wright P., Keenan A.M., Redmond A., Ridgway J. Magnetic Resonance Imaging of synovitis in knees of patients with osteoarthritis without injected contrast agents using $\mathrm{T}_{1}$ quantification. Radiography (Lond), 2018, vol. 24, no. 4, pp. $283-288$. DOI: 10.1016/j.radi.2018.04.009.

60.Ishijima M., Kaneko H., Hada S., Kinoshita M., Sadatsuki R., Liu L., Shimura Y., Arita H., Shiozawa J., Yusup A., Futami I., Sakamoto Y., Ishibashi M., Machida S., Naito H., Arikawa-Hirasawa E., Hamada C., Saita Y., Takazawa Y., Ikeda H., Okada Y., Kaneko K. Osteoarthritis as a cause of locomotive syndrome: its influence on functional mobility and activities of daily living. Clin. Rev. Bone Miner. Metab., 2016, vol. 14, no. 2, pp. 77-104. DOI: 10.1007/s12018-016-9212-6.

Received: 13.03.2019

\section{Information about the authors:}

1. Anastasia V. Sertakova, M.D., Ph.D., Saratov State Medical University named after V.I. Razumovsky, Saratov, Russian Federation, Email: anastasiya-sertakova@yandex.ru

2. Ksenia P. Zvereva, Saratov State Medical University named after V.I. Razumovsky, Saratov, Russian Federation, Email: ksenya.zvereva.91@mail.ru

3. Vladimir V. Zotkin,

Saratov State Medical University named after V.I. Razumovsky, Saratov, Russian Federation, Email: vladimir-zotkin@mail.ru

4. Sergei A. Rubashkin, M.D., Ph.D.,

Saratov State Medical University named after V.I. Razumovsky, Saratov, Russian Federation,

Email: docs@mail.ru

5.Dmitriy I. Anisimov, M.D., Ph.D.,

Saratov State Medical University named after V.I. Razumovsky, Saratov, Russian Federation, Email: anisimovd85@mail.ru 